OPEN ACCESS

Edited by:

Sapna Patel,

University of Texas MD Anderson

Cancer Center, United States

Reviewed by:

Gagan Chhabra,

University of Wisconsin-Madison,

United States

William B. Grant,

Sunlight Nutrition and Health Research

Center, United States

Andrzej T. Slominski,

University of Alabama at Birmingham,

United States

*Correspondence:

Michał Aleksander Żmijewski

mzmijewski@gumed.edu.pl

Specialty section:

This article was submitted to

Skin Cancer

a section of the journal

Frontiers in Oncology

Received: 24 August 2021 Accepted: 01 December 2021 Published: 24 December 2021

Citation:

Piotrowska A, Beserra FP,

Wierzbicka JM, Nowak Jl and Żmijewski MA (2021) Vitamin D Enhances Anticancer Properties of

Cediranib, a VEGFR Inhibitor, by Modulation of VEGFR2 Expression

in Melanoma Cells.

Front. Oncol. 11:763895

doi: 10.3389/fonc.2021.763895

\section{Vitamin D Enhances Anticancer Properties of Cediranib, a VEGFR Inhibitor, by Modulation of VEGFR2 Expression in Melanoma Cells}

\author{
Anna Piotrowska ${ }^{1}$, Fernando Pereira Beserra ${ }^{2}$, Justyna Marta Wierzbicka ${ }^{1}$, \\ Joanna Irena Nowak ${ }^{1}$ and Michał Aleksander Żmijewski ${ }^{1 *}$ \\ ${ }^{1}$ Department of Histology, Faculty of Medicine, Medical University of Gdańsk, Gdańsk, Poland, ${ }^{2}$ Institute of Biosciences, \\ São Paulo State University, São Paulo, Brazil
}

Regardless of the recent groundbreaking introduction of personalized therapy, melanoma continues to be one of the most lethal skin malignancies. Still, a substantial proportion of patients either fail to respond to the therapy or will relapse over time, representing a challenging clinical problem. Recently, we have shown that vitamin D enhances the effectiveness of classical chemotherapeutics in the human malignant melanoma A375 cell line. In search for new combination strategies and adjuvant settings to improve melanoma patient outcomes in the current study, the effects of cediranib (AZD2171), an oral tyrosine kinase inhibitor of VEGFR1-3, PDGFR, and c-KIT, used in combination either with 1,25(OH) 2 $\mathrm{D}_{3}$ or with low-calcemic analog calcipotriol were tested on four human malignant melanoma cell lines (A375, MNT-1, RPMI-7951, and SK-MEL-28). Melanoma cells were pretreated with vitamin $\mathrm{D}$ and subsequently exposed to cediranib. We observed a marked decrease in melanoma cell proliferation (A375 and SK-MEL-28), G2/M cell cycle arrest, and a significant decrease in melanoma cell mobility in experimental conditions used (A375). Surprisingly, concurrently with a very desirable decrease in melanoma cell proliferation and mobility, we noticed the upregulation of VEGFR2 at both protein and mRNA levels. No effect of vitamin D was observed in MNT-1 and RPMI-7951 melanoma cells. It seems that vitamin D derivatives enhance cediranib efficacy by modulation of VEGFR2 expression in melanoma cells expressing VEGFR2. In conclusion, our experiments demonstrated that vitamin D derivatives hold promise as novel adjuvant candidates to conquer melanoma, especially in patients suffering from vitamin D deficiency. However, further extensive research is indispensable to reliably assess their potential benefits for melanoma patients.

Keywords: melanoma, vitamin D, calcipotriol, cediranib, anti-angiogenic therapy, VEGFR, VEGFR inhibitors

\section{INTRODUCTION}

Melanoma, although representing a minor fraction of all skin malignancies, remains the most lethal form $(1,2)$. Before the modern era, patients with advanced melanoma could expect a 5-year survival rate of $10 \%$ (3). Beginning in 2011, novel therapies, including immunotherapy with immune checkpoint inhibitors CTLA-4 or PD-1, as well as targeted therapy with BRAF and MEK inhibitors, have become a key breakthrough in the clinical landscape of melanoma treatment (4). Unprecedented in cancer 
medicine, from 2013 to 2016, overall melanoma mortality decreased by $17.9 \%$ (5). Nevertheless, regardless of the groundbreaking treatment options, most patients invariably relapse from BRAF/ MEK signaling inhibition within a year from treatment commencement (6). About $50 \%$ of patients treated with immune checkpoints inhibitors do not respond due to primary resistance and a great proportion of responders experience tumor relapse within 2 years $(7,8)$. Current 5 -year survival rate for metastatic melanoma is therefore $27 \%$ (9). What is more, the incidence of melanoma is constantly rising worldwide, and currently, melanoma is expected to be the fifth most common cancer in both males and females, as estimated by the American Cancer Society (9). Therefore, it seems to be highly reasonable to focus on new combination strategies and adjuvant settings to improve melanoma patient outcomes (4).

Vitamin D is a secosteroid endogenously produced in the skin from its precursor, 7-dehydrocholesterol, using the energy of UVB irradiation $(10,11)$. It should be emphasized that vitamin D3 is biologically inert and requires two subsequent hydroxylations to gain its hormonal functions. First, hydroxylation at C-25 takes place in the liver, and second, at $\mathrm{C}-1 \alpha$ in kidneys, giving the most active form $1,25(\mathrm{OH})_{2} \mathrm{D}_{3}$, calcitriol $(11,12)$. The extrarenal expression of vitamin $\mathrm{D}$ hydroxylases was proven in many different sites, such as lymph nodes, placenta, breast, and colon (13); however, it should be underlined that the skin is the only organ equipped with the whole pathway of vitamin D synthesis and activation $(14,15)$. Apart from a historically known role in regulation of calcium homeostasis, vitamin $\mathrm{D}$ has widely appreciated anticancer properties, including antiproliferative, antiangiogenic, and pro-differentiative effects in various types of cancer (10). Therefore, vitamin D is considered for cancer prevention, as the recent VITAL study (16-18) and some former studies $(19,20)$ suggest that vitamin D supplementation has beneficial effects in reducing risks of cancer. A very recent study has shown that among patients with newly resected stage II melanoma who received adjuvant vitamin D3 (100,000 IU every 50 days), individuals with low Breslow score $(<3 \mathrm{~mm})$ had a double increase in $25 \mathrm{OHD}$ levels from baseline after 4 months, whereas patients with Breslow score $\geq 3 \mathrm{~mm}$ had a significantly lower increase over time. After 12 months, subjects with low 25OHD levels and Breslow score $\geq 3 \mathrm{~mm}$ had shorter disease-free survival ( $p=0.02$ ) compared to those with Breslow score $<3 \mathrm{~mm}$ and/or high levels of 25OHD (21). At baseline, $80 \%$ of these melanoma patients were vitamin D insufficient (21). This observation underlines the role of vitamin $\mathrm{D}$ supplementation status of patients in melanoma prognosis. Indeed, the National Institute for Health and Care Excellence guidelines clearly recommend that assessment of vitamin D levels and relevant advice should be an inherent aspect of the management of patients with melanoma at the secondary care level (22). Currently, the role of vitamin D supplementation on cutaneous malignant melanoma outcome is assessed in the ViDMe trial (23). Additionally, an inverse correlation has also been documented between the expression of the vitamin $\mathrm{D}$ receptor (VDR) and a crucial vitamin $\mathrm{D}$ activating enzyme (CYP27B1) with melanoma progression and disease outcome (24-26). Furthermore, as revealed by analysis of transcriptome of melanoma patients, VDR expression was independently protective for melanomarelated death in both primary and metastatic disease (27). What is more, it was shown that active forms of vitamin D improve efficacy of several anticancer drugs, such as cisplatin $(28,29)$, dacarbazine (30), doxorubicin (31), and proton therapy (32). It is also suggested that vitamin $\mathrm{D}$ immune-modulating ability could offer indications for a novel vitamin $\mathrm{D}$ application in melanoma patients receiving immunotherapy (33).

Currently, the upper normal limit of $25(\mathrm{OH}) \mathrm{D}$ in blood serum, used in clinic as a biomarker of vitamin D status (34), is defined at $100 \mathrm{ng} / \mathrm{ml}$ (35). A recent study suggests that extended intakes of $20,000 \mathrm{IU} /$ day to $60,000 \mathrm{IU} /$ day, associated with $25 \mathrm{OHD}$ blood levels ranging as high as $384 \mathrm{mg} / \mathrm{dl}$, were found to be safe without any evidence of toxicity (36). However, considering patient safety, the major disadvantage of vitamin $\mathrm{D}$ and its natural active metabolite- $1,25(\mathrm{OH})_{2} \mathrm{D}_{3}$-is that prolonged supplementation with high doses ( $>50,000$ IU per day for several months), which could be beneficial in the cancer therapy, may also lead, although not necessarily, to hypercalcemia $(12,37)$. In our constant work to select most potent but low calcemic vitamin D analogs, we have investigated the series of CYP11A1 metabolites of vitamin D (30, 38, 39 ), which are products of a recently discovered novel pathway of vitamin $\mathrm{D}$ metabolism and activation (40-43), modified vitamin $\mathrm{D}_{2}$ analogs (44), and vitamin D analogs with the shortened side chain $(15,45)$ as to their efficacy against melanoma cell lines. Simultaneously, we have also explored whether vitamin D and its non- or low-calcemic analogs will enhance the effectiveness of classical chemotherapeutics, cisplatin and dacarbazine, in the human malignant melanoma A375 cell line (30). We showed that both calcitriol and calcipotriol exhibited modulatory effects on the melanoma cells treated with dacarbazine, decreasing the half maximal inhibitory concentration (IC50, calcitriol only) for the drug, stimulating G1/G0 arrest, and causing a marked decrease in the mitochondrial transmembrane potential (30). In the current study, we have focused our attention on the antiangiogenic compound, cediranib, and its combination with calcitriol and low-calcemic vitamin D analog, calcipotriol, shown to be as potent as $1,25(\mathrm{OH})_{2} \mathrm{D}_{3}$ in human malignant melanoma cells (30).

\section{MATERIALS AND METHODS}

\section{Chemicals}

$1,25(\mathrm{OH})_{2} \mathrm{D}_{3}$ was purchased in Sigma-Aldrich (Merck KGaA, Darmstadt, Germany). Calcipotriol was a gift from the Pharmaceutical Research Institute (Warsaw, Poland). Cediranib (AZD2171) was purchased from Selleck Chemicals (Houston, TX, USA).

\section{Cell Culture}

Human melanoma A375 cell line (CRL-1619), RPMI-7951 (HTB66), MNT-1, and SK-MEL-28 were from the American Type Culture Collection (Manassas, VA, USA). The A375 cell line is derived from a skin melanoma of a 54-year-old female. It should be underlined that these cells carry two mutant genes, B-RAF and 
CDKN2, both associated with melanoma of sun-damaged skin (46). Since UV radiation is considered the most important environmental risk factor for cutaneous melanoma (47) and it is estimated that $60 \%-70 \%$ of cutaneous malignant melanomas are thought to be caused by ultraviolet (UV) radiation exposure (48), we therefore consider A375 melanoma cells as a particularly good model for our study. A375 cells were cultured in Dulbecco's modified Eagle's medium (DMEM, Sigma-Aldrich; Merck KGaA) supplemented with $10 \%$ fetal bovine serum (FBS) (Biological Industries, Israel) and $1 \%$ penicillin/streptomycin (Sigma-Aldrich; Merck KGaA) in an incubator with $5 \% \mathrm{CO}_{2}$ at $37^{\circ} \mathrm{C}$. RPMI-7951 cells were cultured in Minimum Essential Medium Eagle, with Earle's salts and nonessential amino acids (MEM, Sigma-Aldrich; Merck KGaA), supplemented with 10\% FBS (Biological Industries, Israel), 1\% penicillin/streptomycin (Sigma-Aldrich; Merck KGaA), $1 \mathrm{mM}$ sodium pyruvate, and $2 \mathrm{mM}$ L-glutamine (Sigma-Aldrich; Merck KGaA, both). MNT-1 cells were cultured in MEM (Sigma-Aldrich; Merck KGaA) Alpha Modification, supplemented with 20\% FBS (Biological Industries, Israel), 1\% penicillin/streptomycin, $10 \mathrm{mM}$ HEPES, $2 \mathrm{mM}$ L-glutamine, $1 \mathrm{mM}$ sodium pyruvate, non-essential amino acids (Sigma-Aldrich; Merck KGaA, all listed before), and $10 \%$ AIM-V ${ }^{\mathrm{TM}}$ Medium (Thermofisher Scientific, Waltham, USA). SK-MEL-28 cells were cultured in MEM (Sigma-Aldrich; Merck KGaA) Alpha Modification, supplemented with 10\% FBS (Biological Industries, Israel), 1\% penicillin/streptomycin (SigmaAldrich; Merck KGaA), and $2 \mathrm{mM}$ L-glutamine (Sigma-Aldrich; Merck KGaA). Appropriate medium supplemented with 5 times lower concentration of charcoal-stripped FBS was used for all procedures where the effects of vitamin $\mathrm{D}$ derivatives were examined (2\% for A375, RPMI-7951, and SK-MEL-28 cell lines and $4 \%$ for MNT-1 cells).

\section{Proliferation Assay}

The sulforhodamine B (SRB) assay was performed according to the procedure previously described (49). Briefly, the human melanoma A375 cells were seeded in 96-well plates (3,000 cells per well), cultured overnight, and then treated simultaneously with serial dilutions of cediranib (0.01-1,000 $\mathrm{nM})$ and vitamin D analogs (calcitriol or calcipotriol) at $100 \mathrm{nM}$ concentration, being tested for an additional $72 \mathrm{~h}$. Cells were fixed with $10 \%$ trichloroacetic acid for $1 \mathrm{~h}$ at $4^{\circ} \mathrm{C}$. Following washing $(5 \times$ with distilled water), the staining solution composed of $0.4 \%$ SRB (Sigma-Aldrich; Merck KGaA) in acetic acid was added to each well for $15 \mathrm{~min}$, followed by washing with $1 \%$ acetic acid. The SRB dye was solubilized using a solution of $10 \mathrm{mM}$ buffered Tris Base $(\mathrm{pH} 10.5)$ and the absorbance was measured at $570 \mathrm{~nm}$ using an Epoch ${ }^{\mathrm{TM}}$ microplate spectrophotometer (BioTek Instruments, Inc., Winooski, VT, USA).

\section{Cell Cycle Analysis}

The cell cycle status was analyzed based on quantification of DNA content using flow cytometry. Melanoma cells were treated for $24 \mathrm{~h}$ with vitamin D compounds (calcitriol or calcipotriol) at $100 \mathrm{nM}$ concentration, followed by $72 \mathrm{~h}$ incubation with cediranib at 500 or $1,000 \mathrm{nM}$ concentration. Trypsinized human malignant melanoma cells together with cells from culture medium were fixed in $70 \%$ ethanol for $24-48 \mathrm{~h}$ at $4^{\circ} \mathrm{C}$, then treated with ribonuclease to remove any contaminating RNA, and the DNA was stained with propidium iodide (PI; Sigma-Aldrich; Merck KGaA) for $30 \mathrm{~min}$ at $37^{\circ} \mathrm{C}$. The fluorescence of the PI-stained cells was measured by flow cytometry (FACSCalibur $^{\mathrm{TM}}$; Becton, Dickinson and Company, Franklin, Lakes, NJ, USA). The results were analyzed using the CellQuest ${ }^{\mathrm{TM}}$ Pro Software version 6.0 (Becton, Dickinson and Company) and expressed as a percentage of cells with DNA content corresponding to apoptotic/necrotic cells (subG1 fraction) or cells in G1, S, and G2/ $\mathrm{M}$ phases of the cycle. Supplementary Figure 1 presents row cytometrical data.

\section{Wound Closure Rate}

A375 melanoma cells were seeded on an 8 -well chamber slide $(3 \times$ $10^{5}$ cells per well) and were cultured overnight. Melanoma cells were pretreated with vitamin $\mathrm{D}$ compounds (calcitriol or calcipotriol) at $100 \mathrm{nM}$ concentration. After $24 \mathrm{~h}$, a mechanical wound was created by physical scraping using a pipette tip in a confluent cell monolayer. Cediranib at 500 or $1,000 \mathrm{nM}$ concentration was diluted in a fresh medium and added to the cells for $72 \mathrm{~h}$ and cell migration process was observed. The experiment was carried out as a live imaging with Olympus cellVivo IX83 and cell free area was calculated as a percentage closure relative to original size [(wound area in $\left.\mu \mathrm{m}^{2}\right)^{\star} 100 /$ (original wound area in $\mu \mathrm{m}^{2}$ )] with the Olympus cellSens software with use of TruAI technology.

\section{VEGFR2 Extracellular Expression}

A375 melanoma cells were treated for $24 \mathrm{~h}$ with vitamin D compounds (calcitriol or calcipotriol) at $100 \mathrm{nM}$ concentration, followed by $24 \mathrm{~h}$ incubation with cediranib at 500 or $1,000 \mathrm{nM}$ concentration. Trypsinized human malignant melanoma cells at $1 \times$ $10^{6}$ density were harvested by centrifugation and rinsed two times in $3 \mathrm{ml}$ of incubation buffer ( $0.5 \%$ bovine serum albumin in PBS). Following $10 \mathrm{~min}$ blocking in the incubation buffer, cells were stained for $30 \mathrm{~min}$ at room temperature with primary antibody antiVEGFR2 (Cell Signaling, cat. no. 2479, rabbit monoclonal, 1:200) dissolved in the incubation buffer. Following rinsing $2 \times$ in incubation buffer, cells were incubated for $30 \mathrm{~min}$ with the secondary antibody (goat anti-rabbit IgG ThermoFisher Scientific A11008, 1:500) diluted in the incubation buffer. Cells were rinsed $2 \times$ with incubation buffer, dissolved in $0.5 \mathrm{ml}$ of PBS and analyzed cytometrically on FACSCalibur $^{\mathrm{TM}}$ (Becton, Dickinson and Company, Franklin, Lakes, NJ, USA) using the CellQuest ${ }^{\mathrm{TM}}$ Pro Software version 6.0 (Becton, Dickinson and Company). The results were expressed as a fluorescence geometric mean.

\section{Immunoblotting}

After preincubation either with $1,25(\mathrm{OH})_{2} \mathrm{D}_{3}$ or with calcipotriol at $100 \mathrm{nM}$ concentration for $24 \mathrm{~h}, \mathrm{~A} 375$, SK-MEL-28, RPMI-7951 or MNT-1 melanoma cells were treated for an additional $24 \mathrm{~h}$ with cediranib at 500 or $1,000 \mathrm{nM}$ concentration. Subsequently, cells were scraped and lysed in the presence of ice-cold RIPA buffer (Sigma-Aldrich; Merck KGaA) supplemented with protease inhibitor cocktail. Protein concentrations were determined by the Bradford assay. An equal amount of protein from each sample (40 $\mu \mathrm{g}$ ) was loaded per lane, and proteins were resolved by SDS-PAGE (4\%-20\% Mini-PROTEAN ${ }^{\circledR}$ TGX Stain-Free ${ }^{\text {TM }}$ Protein Gels, BioRad Laboratories, Hercules, CA, USA) and then transferred onto an Immun-Blot ${ }^{\mathrm{TM}}$ PVDF membrane (Bio-Rad Laboratories, Hercules, 
CA, USA). The membranes were incubated with primary antibodies: anti-VDR (mouse monoclonal, 1:1,000; Santa Cruz sc13133), anti-VEGFR1 (rabbit polyclonal, 1:1,000; Cell Signaling Technology 2893), anti-VEGFR2 (rabbit monoclonal, 1:1,000; Cell Signaling Technology 2479), anti-PDGFR alpha (rabbit monoclonal, 1:1,000; Cell Signaling Technology 3174), antiPDGFR beta (rabbit monoclonal, 1:1,000; Cell Signaling Technology 3169), or HRP-conjugated anti- $\beta$-actin antibody (mouse monoclonal, 1:10,000; Santa Cruz Biotechnology, sc47778 ) overnight at $4^{\circ} \mathrm{C}$. After three washes in TBST, secondary goat anti-rabbit antibodies conjugated to horseradish peroxidase (1:10,000; Santa Cruz Biotechnology, sc-2004) or secondary bovine anti-mouse antibodies conjugated to horseradish peroxidase (1:20,000; Santa Cruz Biotechnology, sc-2371) were added, and following incubation for $1 \mathrm{~h}$ at room temperature, blots were developed with Western Lightning ${ }^{\circledR}$ Ultra chemiluminescent substrate (PerkinElmer, Inc. Waltham, MA, USA) according to the manufacturer's protocol. Changes in protein level were assessed by densitometric scanning of the bands and corrected for $\beta$-actin loading control.

\section{Immunocytochemistry}

A375 melanoma cells were seeded in 8-well chambers. Cells were preincubated for $24 \mathrm{~h}$ with vitamin $\mathrm{D}$ derivatives at $100 \mathrm{nM}$ concentration and subsequently incubated for an additional $24 \mathrm{~h}$ with cediranib at 500 or $1,000 \mathrm{nM}$ concentration. Following fixing with $4 \%$ paraformaldehyde (PFA) for $10 \mathrm{~min}$ at room temperature (RT), cells were permeabilized in $0.2 \%$ Triton X-100 solution in PBS for 10 min. Blocking was performed with $1 \%$ BSA in PBS for $30 \mathrm{~min}$ at RT. Following washing $3 \times 5 \mathrm{~min}$ in PBS, primary antibodies were applied to the cells (VEGFR2 rabbit monoclonal, 1:200; Cell Signaling Technology 2479; EEA1 mouse monoclonal, 1:250, BD Biosciences 610457) and incubated at $4^{\circ} \mathrm{C}$ overnight. Following rinsing $3 \times 5 \mathrm{~min}$ in PBS, slides were incubated with an appropriate secondary antibody (A11008 goat anti-rabbit IgG Alexa Fluor 488, 1:500; A11008 donkey anti-mouse IgG Alexa Fluor 594, 1:500, Life Technologies) for $1 \mathrm{~h}$ at RT. Following rinsing, cultures were counterstained with DAPI (Sigma-Aldrich; Merck KGaA). Images were collected with Olympus cellVivo IX83 and analyzed with Olympus cellSens software.

\section{RT-PCR}

After preincubation either with $1,25(\mathrm{OH})_{2} \mathrm{D}_{3}$ or with calcipotriol at $100 \mathrm{nM}$ concentration for $24 \mathrm{~h}, \mathrm{~A} 375$ melanoma cells were treated for an additional $24 \mathrm{~h}$ with cediranib at 500 or $1,000 \mathrm{nM}$ concentration. Subsequently, total RNA was extracted by using the ExtractME ${ }^{\circledR}$ Total RNA Kit (Blirt, Poland, EM09.1-250), according to the manufacturer's instructions. The concentration and purity of isolated RNA were measured by an EpochMicroplate Spectrophotometer (BioTek, USA). Extracted RNA was reverse transcribed and cDNA synthesized using RevertAid ${ }^{\mathrm{TM}}$ First Strand cDNA Synthesis Kit (Thermo Fisher Scientific Inc., USA). Real-Time PCR was performed using a StepOnePlus ${ }^{\mathrm{TM}}$ Real-Time PCR System (LifeTechnologies-Applied Biosystems, Grand Island, NY, USA) with RealTime AMPLIFYME SYBR ${ }^{\mathrm{TM}}$ Green No-ROX Mix (Blirt, Poland, AM01). All primers were purchased from Sigma-Aldrich (Merck KGaA). The expression of the genes was normalized by comparative $-\Delta \Delta \mathrm{Ct}$ method, using RPL37A as a housekeeping gene, followed by calibration (fold change) to normalized expression data of samples from control (ratio = 1). To ensure specificity of the PCR amplification, dynamic melting curve analysis was performed for all reactions. Primer sequences are summarized in Table 1.

\section{Statistical Analyses}

Statistical analysis was performed using GraphPad Prism v 7.05 (GraphPad Software, San Diego, CA, USA) or Microsoft Excel. Data were subjected to Student's $t$-test (for two groups), one-way or two-way analysis of variance and appropriate post-hoc test (the ANOVA Tukey's or Sidak's multiple comparison test). Data are expressed as mean of 3 to 5 independent experiments \pm S.D $(n=2-6$ in each). Differences are shown as significant at ${ }^{*} p<0.05,{ }^{* *} p<0.01$, ${ }^{* * *} p<0.001$, or ${ }^{* * * *} p<0.0001$ as indicated.

\section{RESULTS}

\section{Vitamin D Analogs Significantly Decrease Viability of A375 and SK-MEL-28 Melanoma Cells Treated With Cediranib}

As established by SRB proliferation assay, cediranib alone inhibited A375 melanoma cell proliferation maximally about 6\% at 1,000 $\mathrm{nM}$ concentration during $72 \mathrm{~h}$ of incubation (Figures 1A,

TABLE 1 | Primer sequences.

\begin{tabular}{lll}
\hline Gene & Forward primer 3'-5' & Reverse primer 5'-3' \\
\hline RPL37A & TTCTGATGGCGGACTTACC & CACTTGCTCTTCTGTGGCA \\
VEGFR1 & TCCAAGAAGTGACACCGAGA & TTGTGGGCTAGGAAACAAGG \\
VEGFR2 & GACTTGGCCTCGGTCATTA & ACACGACTCCATGTGGTCA \\
PDGRFa & TGGATTGACCCTGCTGATG & ATCAGCCTGCTT CATGTCCAT \\
PDGFRb & CACAATGACTCCCGTGGACTG & CATCATTAGGGAGGAACCCA \\
VEGFA & AAGGAGGAGGGCAGAATCAT & GCAGTAGCTGCGCTGATAGA \\
VEGFC & TGAACACCAGCACGAGCTAC & GCCTTGAGAGAGAGGCACTG \\
VEGFD & TGGAACAGAAGACCACTCTCATCT \\
VDR & CCAGTCGTGTGATGATGG & GCAACGATCTTCGTCAAACATC \\
CYP27B1 & TGTTGCATTGCTCAGA & GTCGTCCATGGTGAAGA \\
CYP2R1 & AGAGACCCAGAAGTGTCCAT \\
CYP3A4 & AAGGCACCACCCACCTATGATACT & CCGGGAGAGCTCATACAG \\
CYP24A1 & GCAGCCTAGTGCAGATT & GTCTTCAGCACAGATGAGGTA \\
& & TACTITGGTCACGGTGAAGAGCA \\
\end{tabular}


B). However, simultaneous treatment with cediranib and 1,25 $(\mathrm{OH})_{2} \mathrm{D}_{3}$ or calcipotriol, at $100 \mathrm{nM}$ concentration, resulted in a profound decrease in the proliferation of melanoma cells. The effect of vitamin D derivatives varied as to the level of maximal inhibition of melanoma cell proliferation, which ranged from approximately $30 \%$ for cediranib and $1,25(\mathrm{OH})_{2} \mathrm{D}_{3}$ (Figure 1A) to $43 \%$ for cediranib and calcipotriol (Figure 1B), $p<0.0001$ both. Similar effects were observed in SK-MEL-28 melanoma cells. Cediranib alone inhibited proliferation of the cells maximally about $12 \%$ at $1,000 \mathrm{nM}$ under experimental conditions used (Figures 1C, D). Simultaneous treatment with cediranib and $1,25(\mathrm{OH})_{2} \mathrm{D}_{3}$ or calcipotriol, at $100 \mathrm{nM}$ concentration, resulted in further decrease in the proliferation of melanoma cells. The effect of vitamin $\mathrm{D}$ derivatives varied as to the level of maximal inhibition of melanoma cell proliferation, which ranged from approximately $26 \%$ for cediranib and $1,25(\mathrm{OH})_{2} \mathrm{D}_{3}$ (Figure 1C) to $22 \%$ for cediranib and calcipotriol (Figure 1D), $p<.05$ both. On the other hand, treatment of MNT-1 and RPMI-7951 melanoma cells with cediranib in the presence of $1,25(\mathrm{OH})_{2} \mathrm{D}_{3}$ (Figures $\mathbf{1 E}-\mathbf{H}$ ) or calcipotriol did not show additive effect of co-treatment. Cediranib alone inhibited proliferation of these melanoma cells maximally about $11 \%$ or $18 \%$, respectively, at $1,000 \mathrm{nM}$ concentration during $72 \mathrm{~h}$ of incubation.

\section{Vitamin D Derivatives Trigger G2/M Cell Cycle Arrest in A375 Malignant Melanoma Cells Treated With Cediranib}

Since the most profound effect of vitamin D analogs to the inhibition of melanoma cell proliferation treated with cediranib was observed in A375 cells, this line was used as a model for further detailed analysis. In agreement with our previous studies $(15,44)$, treatment of A375 melanoma cells with vitamin D resulted in G0/G1 (G0/G1 - stationary/growth phase) cell cycle arrest (Figures 2A, B). G0/G1 arrest was observed also in

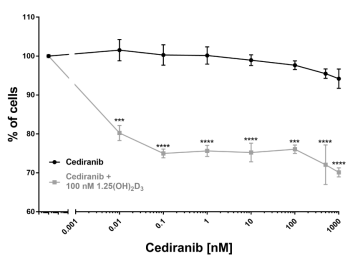

C

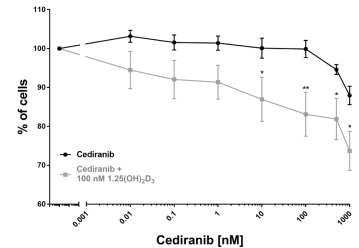

E

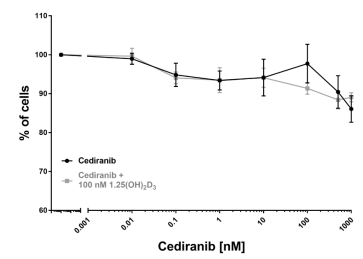

G

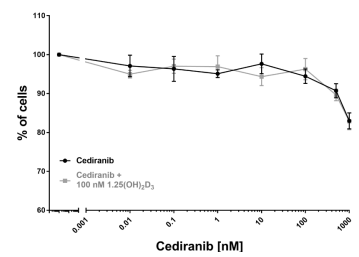

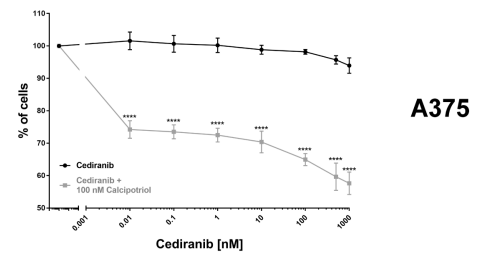

D

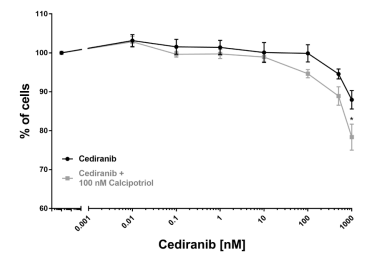

SK-MEL-28

F

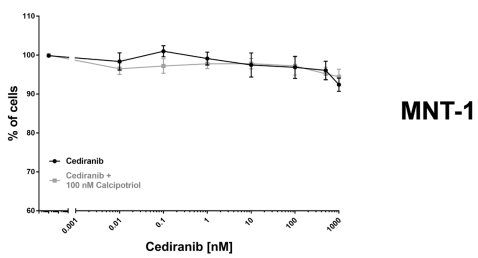

H

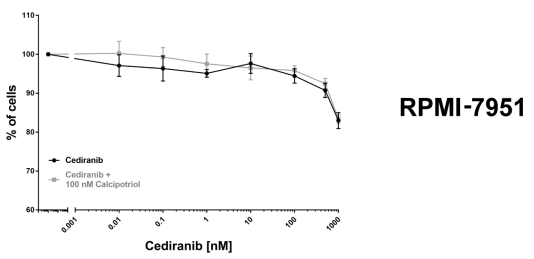

FIGURE 1 | The effect of cediranib or its combination with vitamin $\mathrm{D}$ analogs [left column $-1,25(\mathrm{OH})_{2} \mathrm{D}_{3}$; right column - calcipotriol] on the proliferation of human malignant melanoma A375, MNT-1, RPMI-7951, and SK-MEL-28 cells [(A, B)-A375; (C, D) - SK-MEL-28; (E, F) - MNT-1 and (G, H) - RPMI-7951 cell lines]. The cells were treated with serial dilutions $(0.01-1,000 \mathrm{nM})$ of cediranib alone or in combination either with $1,25(\mathrm{OH})_{2} \mathrm{D}_{3}$ or with calcipotriol for $72 \mathrm{~h}$. The same cediranib data are plotted in each graph from the same melanoma cell line, except for MNT-1 cells. Data are shown as mean from three or four independent experiments $(n=$ 4-6 in each) \pm SEM. Statistical significance between plots (between relevant concentrations of cediranib alone or with vitamin D) was estimated using two-way ANOVA and presented as ${ }^{\star} p<0.05 ;{ }^{* \star} p<0.01,{ }^{\star \star *} p<0.001$, or ${ }^{\star \star \star \star} p<0.0001$. 
melanoma cells treated with cediranib, $p<0.0001$ (Figure 2). Additionally, we noticed an increase in the number of SubG1 cells, indicating induction of apoptosis by cediranib in melanoma cells, $p<0.0001$ (Figure 2). To investigate the mechanism of proliferation inhibition of melanoma A375 cells by the combination of vitamin $\mathrm{D}$ analogs with cediranib, melanoma cells were pretreated either with $1,25(\mathrm{OH})_{2} \mathrm{D}_{3}$ (Figure 2A) or with calcipotriol (Figure 2B) at $100 \mathrm{nM}$ concentration for $24 \mathrm{~h}$ and then incubated with cediranib at 500 or $1,000 \mathrm{nM}$ for an additional $72 \mathrm{~h}$. Preincubation of melanoma cells with $1,25(\mathrm{OH})_{2} \mathrm{D}_{3}$ (Figure 2A) prior to cediranib treatment for $72 \mathrm{~h}$ resulted in an increase in the percentage of cells in the G2/M phase (preparation for mitosis/mitosis) in comparison to cells without pretreatment, $p<0.001$ for cediranib at $500 \mathrm{nM}$ concentration and $p<0.05$ for cediranib at $1,000 \mathrm{nM}$ concentration (Figure 2A), which was accompanied by a proportional decrease in the number of SubG1 cells (SubG1apoptotic/necrotic cells). Similar results were observed for calcipotriol (Figure 2B); however, we noticed an increase in the percentage of cells not only in the G2/M phase, but also in the $S$ phase, in comparison to cells without pretreatment.

\section{Pretreatment With Vitamin D Derivatives Significantly Decreases Mobility of A375 Melanoma Cells Treated With Cediranib}

Cellular motility and migration are well-established hallmarks of malignant tumors spreading their metastases (50). We recorded therefore migration of A375 melanoma cells and wound closure live with Olympus cellVivo IX83 every $30 \mathrm{~min}$ for $72 \mathrm{~h}$ and cell free area was calculated as a percentage of closure relative to its original size. The wound closure curves (Figure 3) revealed that non-treated malignant melanoma
A

B

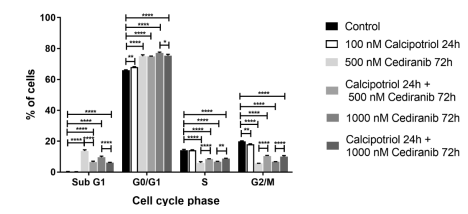

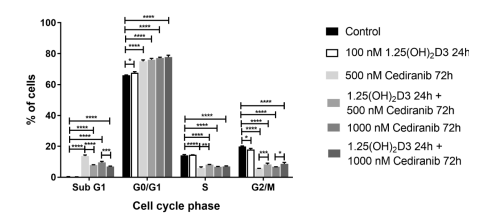

FIGURE 2 | The effect of 24-h preincubation with $1,25(\mathrm{OH})_{2} \mathrm{D}_{3}$ (A) or calcipotriol (B) at $100 \mathrm{nM}$ concentration on the distribution of human malignant melanoma A375 cells treated for $72 \mathrm{~h}$ with cediranib throughout the phases of the cell cycle (SubG1 - apoptotic/necrotic cells, G1-growth, S-DNA synthesis, G2/M-preparation for mitosis/mitosis). Cells were harvested, stained with propidium iodide, and analyzed by flow cytometry. The data are presented as the mean \pm standard deviation $(n=3)$. The same control and cediranib data are plotted in each graph. Statistical significance was estimated using two-way ANOVA followed by Tukey's multiple comparison test and presented as ${ }^{*} p<$ $0.05 ;{ }^{* \star} p<0.01 ;{ }^{* \star} p<0.001,{ }^{* \star \star *} p<0.0001$. The results are representative of four experiments.
A375 cells approached up to $38 \%$ closure and migrate faster than cells from any treatment groups $(p<0.0001$ for any treatment group vs. control, not marked in Figure 3). In agreement with our previous study (15), we observed that $1,25(\mathrm{OH})_{2} \mathrm{D}_{3}$ efficiently inhibited melanoma cell migration ( $p<0.0001$ vs. control, not marked in Figure 3) during 72 h, leaving approximately $70 \%$ of the wound original size. Interestingly, calcipotriol was even more efficient than $1,25(\mathrm{OH})_{2} \mathrm{D}_{3}$, leaving as much as $81.5 \%$ of the wound original size. Curiously, cediranib at both tested concentrations, 500 and $1,000 \mathrm{nM}$, inhibited melanoma cell migration to a similar extent, leaving approximately $74 \%-75 \%$ of the wound original size. It should be emphasized, however, that vitamin $\mathrm{D}$ pretreatment profoundly diminished cellular mobility in melanoma cells treated with cediranib. The most efficient reduction of melanoma cells mobility was observed in cells $24 \mathrm{~h}$ pretreated with $1,25(\mathrm{OH})_{2} \mathrm{D}_{3}$ and incubated subsequently for $72 \mathrm{~h}$ with cebiranib at $500 \mathrm{nM}$, in which the wound area was reduced by only $15 \%\left[p<0.0001\right.$ for melanoma cells $1,25(\mathrm{OH})_{2} \mathrm{D}_{3}$ pretreated and incubated with cediranib at $500 \mathrm{nM}$ concentration vs. 500 $\mathrm{nM}$ cediranib alone; Figure 3], giving a further significant $10 \%$ reduction in cellular mobility as compared to monotreatment with cediranib. Substantial $8 \%$ reduction in cellular mobility was observed also in melanoma cells pretreated with calcipotriol compared to monotreatment with cediranib.

\section{Vitamin D Derivatives Increase the Extracellular Expression of VEGFR2 in A375 Malignant Melanoma Cells Treated With Cediranib}

Since cediranib is a small-molecule inhibitor of several tyrosine kinases, including VEGFR1 and VEGFR2, of which the latter seems to play a predominant role (51), we investigated therefore whether vitamin $\mathrm{D}$ preincubation will affect the extracellular expression of VEGFR2 in A375 melanoma cells exposed to cediranib. We noticed that cediranib alone did not influence the extracellular expression of VEGFR2 in A375 melanoma cells during 24-h incubation (Figure 4). However, the extracellular expression of VEGFR2 increased significantly in melanoma cells pretreated either with $1,25(\mathrm{OH})_{2} \mathrm{D}_{3}$ (Figure 4A) or with calcipotriol (Figure 4B) for $24 \mathrm{~h}$ as compared to monotreatment with cediranib or to control cells.

\section{Vitamin D Derivatives Upregulate VEGFR2 Protein Level in Malignant Melanoma Cells Treated With Cediranib}

Next, we checked whether the preincubation of A375 melanoma cells with vitamin $\mathrm{D}$ derivatives affected the protein level of VEGFR1, VEGFR2, PDGFRa, PDGFRb, or VDR after subsequent treatment with cediranib (Figure 5). No significant effect was observed as to the VEGFR1 or PDGFRb protein level neither by $1,25(\mathrm{OH})_{2} \mathrm{D}_{3}$, nor by cediranib under the experimental conditions used (Figures 5A, E, respectively). We also noticed that the expression of VEGFR2 at the protein level was not changed by cediranib alone (Figure 5B). However, we 

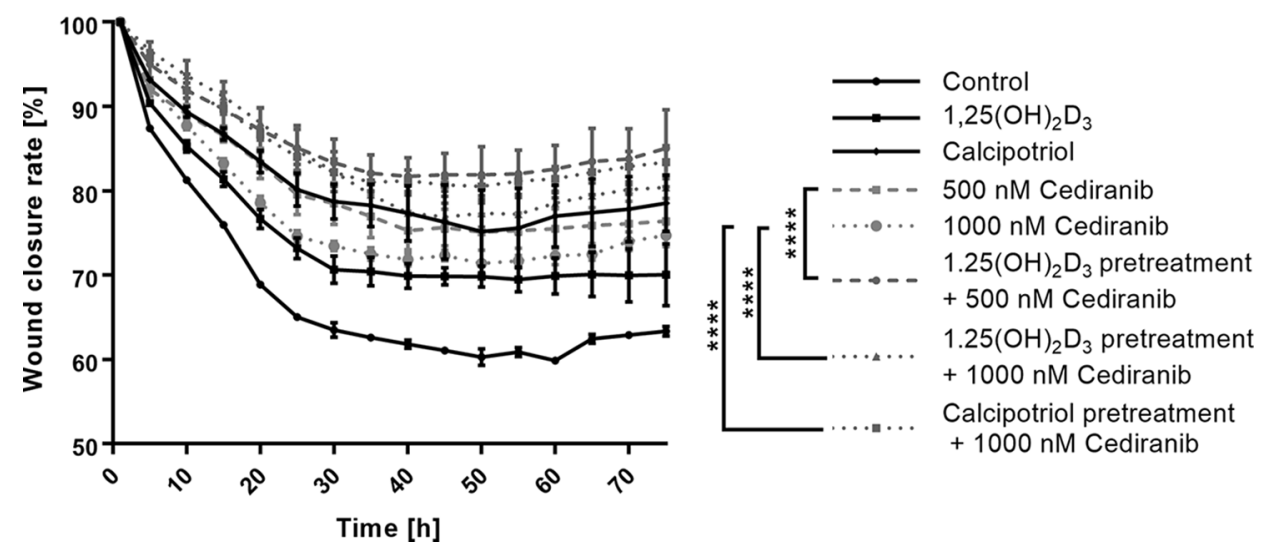

FIGURE 3 | The effect of 24-h preincubation with vitamin D analogs at $100 \mathrm{nM}$ concentration on the rate of a wound closure in A375 human malignant melanoma cells treated for $72 \mathrm{~h}$ with cediranib either at 500 or at 1,000 nM concentration. The cell-free area of each wound was measured at the different time points, every 30 min for $72 \mathrm{~h}$ as a live imaging in Olympus cell Vivo IX 83, and results were calculated in \% as a wound closure rate with the Olympus cell Vivo IX 83 software.

Statistical values were calculated with one-way analysis of variance and Tukey's post-hoc test and presented as ${ }^{\star \star \star \star} p<0.0001$.

observed a significant increase in VEGFR2 protein level in melanoma cells pretreated with vitamin $\mathrm{D}$ (although in case of calcipotriol, only with cediranib at $500 \mathrm{nM}$ concentration). Both vitamin $\mathrm{D}$ derivatives increased the VDR protein level (Figure 5C). Cediranib alone increased the protein level of PDGFRa $(p<0.05)$, while preincubation with $1,25(\mathrm{OH})_{2} \mathrm{D}_{3}$ reversed that effect for cediranib at $1,000 \mathrm{nM}$ concentration, $p<0.01$ (Figure 5D).

Since we observed the upregulation of VEGFR2, at both protein level and its extracellular expression, under experimental conditions, concurrently with a very desirable decrease in A375 melanoma cell proliferation and mobility, we hypothesized whether the presence of VEGFR2 protein or its level could potentially influence the extent to which $1,25(\mathrm{OH})_{2} \mathrm{D}_{3}$ may enhance the cytotoxic effect of cediranib in MNT-1, RPMI-7951, and SK-MEL-28 melanoma cells. We checked, therefore, whether the preincubation of aforementioned melanoma cell lines with $1,25(\mathrm{OH})_{2} \mathrm{D}_{3}$ affected the protein level of VEGFR2, PDGFRa, or
VDR, after subsequent treatment with cediranib (Figure 6). No significant effect was observed as to the VDR protein level neither by $1,25(\mathrm{OH})_{2} \mathrm{D}_{3}$, nor by cediranib under the experimental conditions used in MNT-1 melanoma cells (Figure 6). However, we observed a significant increase in VDR protein level in RPMI7951 and SK-MEL-28 melanoma cells treated with $1,25(\mathrm{OH})_{2} \mathrm{D}_{3}$ (Figures 6C, I). No significant effect was observed as to the PDGFRa protein level neither by $1,25(\mathrm{OH})_{2} \mathrm{D}_{3}$, nor by cediranib under the experimental conditions used in RPMI-7951 and SKMEL-28 melanoma cells (Figures 6B, $\mathbf{H}$ ); what is more, we did not detect any PDGFRa protein product in MNT-1 melanoma cells (Figure 6E). Interestingly, we did not detect any VEGFR2 protein product neither in MNT-1, nor in RPMI-7951 melanoma cells (Figures 6D, G). However, we observed a significant increase in VEGFR2 protein level in SK-MEL-28 melanoma cells treated with cediranib alone or cediranib with $1,25(\mathrm{OH})_{2} \mathrm{D}_{3}$ (Figure 6A), which underlines the key role of VEGFR2 in an interaction between vitamin $\mathrm{D}$ and cediranib.
A

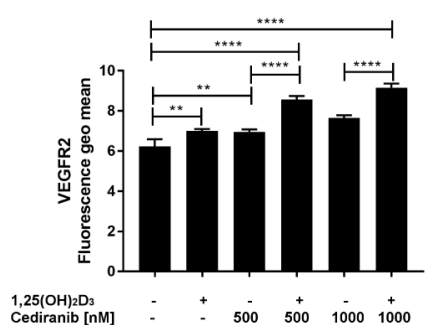

B

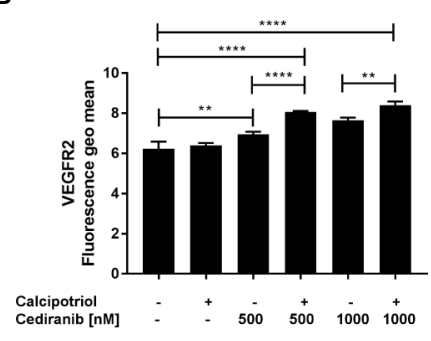

FIGURE 4 | The effect of 24-h preincubation with 1,25(OH)2D3 (A) or calcipotriol (B) at $100 \mathrm{nM}$ concentration on the extracellular expression of the VEGFR2 in A375 melanoma cells treated subsequently for $24 \mathrm{~h}$ with cediranib at 500 or 1,000 nM concentration. Cells were stained with appropriate antibody (see Materials and Methods section) and analyzed cytometrically. The data are presented as the mean \pm standard deviation $(n=3)$. The same control and cediranib data are plotted in each graph. Statistical significance was estimated using one-way ANOVA followed by Tukey's multiple comparison test and presented as ${ }^{\star \star} p<0.01$ or ${ }^{* \star \star *} p<0.0001$. The results are representative of three experiments. 
A

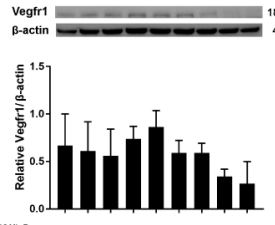

D

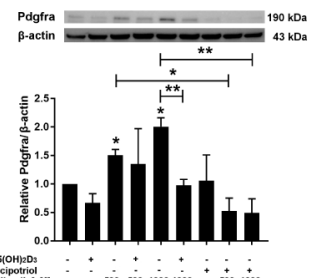

B

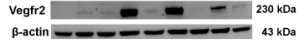

Bactin

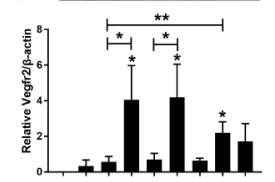

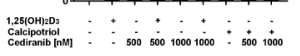

E Pdgrti

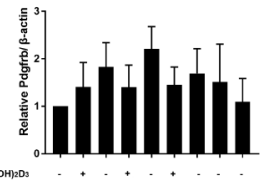

C vdr

Bactin - - -
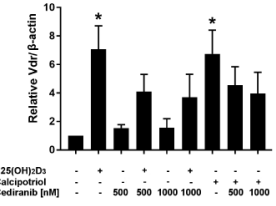

FIGURE 5 | The effect of 24-h preincubation with vitamin D analogs at $100 \mathrm{nM}$ concentration on VEGFR1 (A), VEGFR2 (B), VDR (C), PDGFRa (D), and PDGFRb (E) protein level in A375 melanoma cells treated subsequently for $24 \mathrm{~h}$ with cediranib at 500 or 1,000 nM concentration. Protein levels were measured by Western blotting, with $\beta$-actin used as a control. Data are shown as mean from three independent experiments \pm SEM. ${ }^{*} p<0.05$ and ${ }^{* *} p<0.01$ vs. untreated control or between the two groups indicated by the bracket.

To further explore the mechanism underlying the observed increase of VEGFR2 protein level by vitamin D in A375 melanoma cells treated with cediranib, we checked whether this protein is sequestered in early endosomes for potential recycling or degradation, as suggested recently (52). We did not observe, however, any colocalization of VEGFR2 and EEA1, which is a marker of early endosomes (Figure 7).
A
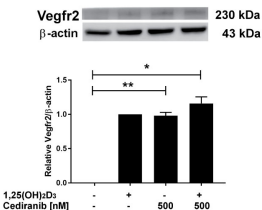

D
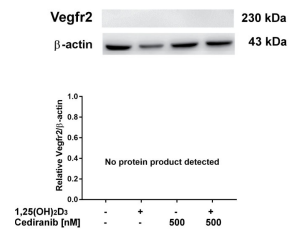

G

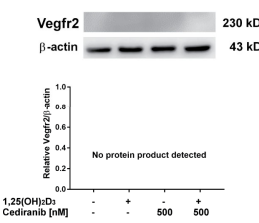

B
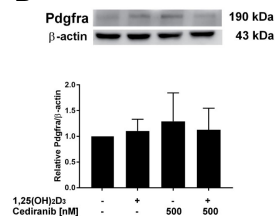

E
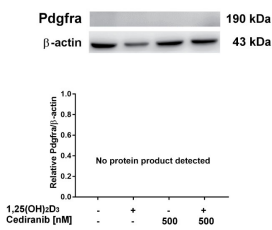

H

Pdgra $-\cdots-190 \mathrm{kDa}$

B.actin

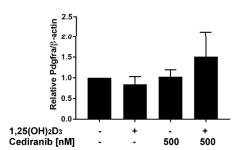

C

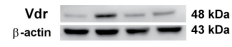

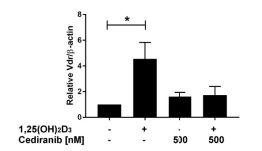

$\mathbf{F}$
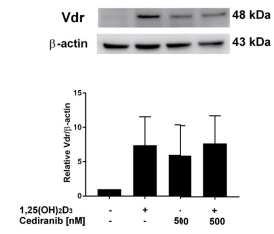

MNT-1

I

$\mathrm{vdr}=--{ }^{48 \mathrm{kda}}$

B-actin $-\longrightarrow-13$ kDa

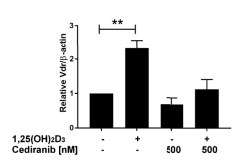

SK-MEL-28

RPMI-7951

FIGURE 6 | The effect of 24-h preincubation with $1,25(\mathrm{OH})_{2} \mathrm{D}_{3}$ at $100 \mathrm{nM}$ concentration on VDR (C, F, I), PDGFRa (B, E, H), and VEGFR2 (A, D, G) protein level in SK-MEL-28 (A-C), MNT-1 (D-F), and RPMI-7951 (G-I) melanoma cells treated subsequently for $24 \mathrm{~h}$ with cediranib at $500 \mathrm{nM}$ concentration. Protein levels were measured by Western blotting, with $\beta$-actin used as a control. Data are shown as mean from three independent experiments \pm SEM. Statistical significance was estimated using one-way ANOVA followed by Tukey's multiple comparison test and presented as ${ }^{*} p<0.05$ and ${ }^{* *} p<0.01$ vs. untreated control or between the two groups indicated by the bracket. 


\section{Vitamin D Derivatives Modulate Expression of VEGFR2, VEGFA, PDGFRa, and PDGFRb at the mRNA Level in A375 Malignant Melanoma Cells Treated With Cediranib}

In order to verify the aforementioned changes in protein level, the impact of $1,25(\mathrm{OH})_{2} \mathrm{D}_{3}$ on the expression of selected VEGFassociated genes was tested in melanoma cells treated with cediranib (Figure 8). Although cediranib alone did not influence mRNA level for VEGFR1 (Figure 8A), we observed an increase in mRNA level in melanoma cells treated with the combination of $1,25(\mathrm{OH})_{2} \mathrm{D}_{3}$ and cediranib at both tested concentrations ( $p<0.05$ vs. control). No significant effect of cediranib alone was observed on the mRNA level of VEGFR2; however, consistent with immunoblotting described above, we observed a marked increase in VEGFR2 mRNA level in melanoma cells pretreated with $1,25(\mathrm{OH})_{2} \mathrm{D}_{3}(p<0.01$, Figure 8B). Both $1,25(\mathrm{OH})_{2} \mathrm{D}_{3}$ and cediranib resulted in an increase in mRNA level for VEGFR3 ( $p<0.05$, Figure 8C), with an increasing trend in melanoma cells pretreated with vitamin $\mathrm{D}$ subsequently exposed to cediranib, yet without statistical significance in the latter. Interestingly, cediranib alone at 500 $\mathrm{nM}$ concentration decreased the mRNA level for VEGF-A ( $p<$ 0.01 , Figure 8D), while pretreatment of A375 melanoma cells with $1,25(\mathrm{OH})_{2} \mathrm{D}_{3}$ resulted in an increase in the relevant mRNA in melanoma cells incubated subsequently with cediranib at $1,000 \mathrm{nM}$ concentration $(p<0.05)$. No significant effect was observed in the expression of VEGF-C under the experimental conditions used (Figure 8E). mRNA level for VEGF-D was elevated by both $1,25(\mathrm{OH})_{2} \mathrm{D}_{3}$ and cediranib $(p<0.05$, Figure 8F), and it was elevated also in melanoma cells pretreated with vitamin D. Finally, we observed an increase in
mRNA level for PDGFRa and PDGFRb in melanoma cells treated with cediranib at $1,000 \mathrm{nM}$ concentration $(p<0.05$, Figures 8G, H, respectively); the effect was further exacerbated by vitamin D pretreatment $(p<0.05$ for PDGFRa and $p<0.01$ for PDGFRb vs. monotreatment).

Then, we also analyzed the expression of several vitamin Drelated genes in the experimental conditions used. We observed that VDR mRNA level was elevated in A375 melanoma cells pretreated with vitamin $\mathrm{D}$ and subsequently incubated with cediranib at $1,000 \mathrm{nM}$ concentration ( $p<0.05$, Figure 9A). No significant effect was observed in the expression of CYP27B1 under the experimental conditions used (Figure 9B). Cediranib treatment resulted, however, in an increase in mRNA level for CYP3A4 and CYP2R1 in melanoma cells pretreated with 1,25 $(\mathrm{OH})_{2} \mathrm{D}_{3}(p<0.05$ vs. control and vs. monotreatment, Figures 9C, D, respectively). Lastly, consistent with our previous results (30) and literature data (53), we observed a marked increase in mRNA level for CYP24A1 $(p<0.01$, Figure 9E) in melanoma cells treated with $1,25(\mathrm{OH})_{2} \mathrm{D}_{3}$. Interestingly, the effect was invariably observed in cells treated subsequently with cediranib. In fact, the mRNA level of CYP24A1 was the highest in melanoma cells treated with cediranib following vitamin D pretreatment $(p<0.01$ vs. monotreatment).

\section{DISCUSSION}

Advanced metastatic melanoma is widely known as one of the most aggressive skin malignancies. Regardless of improvements in the recent decade, a remarkable proportion of patients still fail to respond to the therapy or will relapse over time (4). Increased
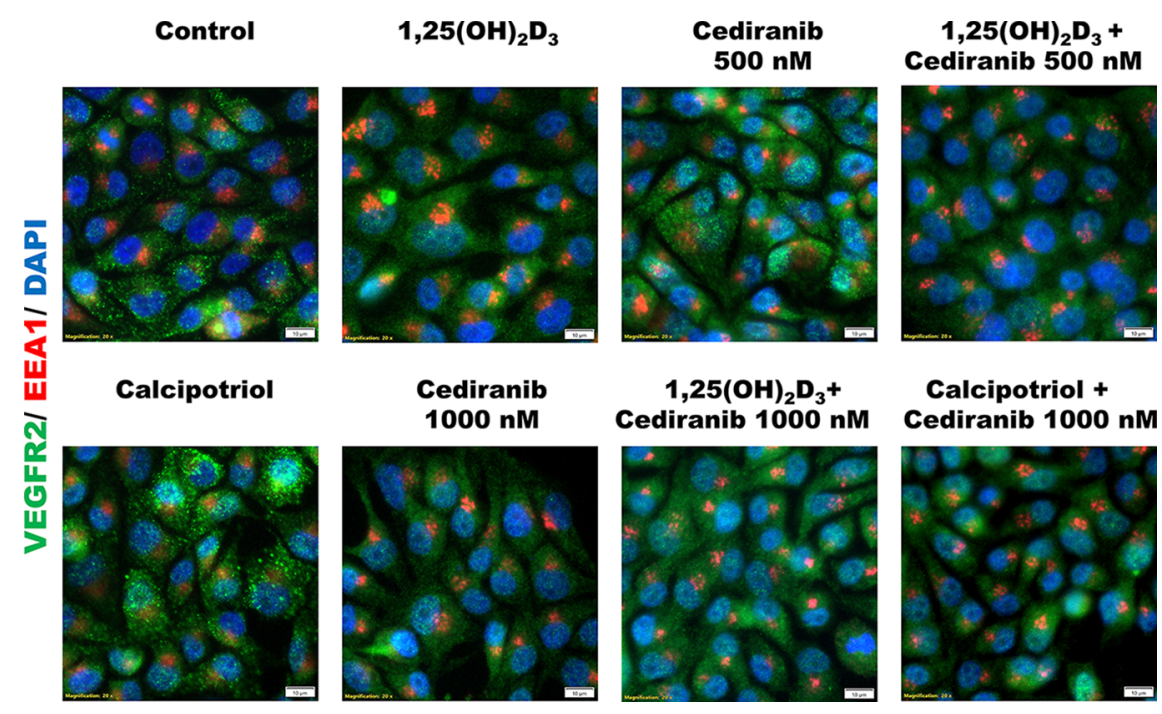

Calcipotriol +
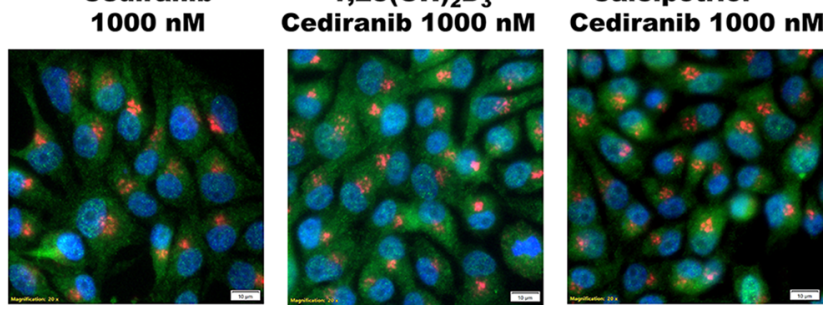

FIGURE 7 | Immunofluorescent detection of VEGFR2 (green) or EEA1 (red) in A375 melanoma cells. Melanoma cells were preincubated with vitamin D derivatives for $24 \mathrm{~h}$ and subsequently treated with cediranib at 500 or 1,000 nM concentration for another $24 \mathrm{~h}$. Nuclei were counterstained with DAPI (shown in blue). Magnification 200x. 

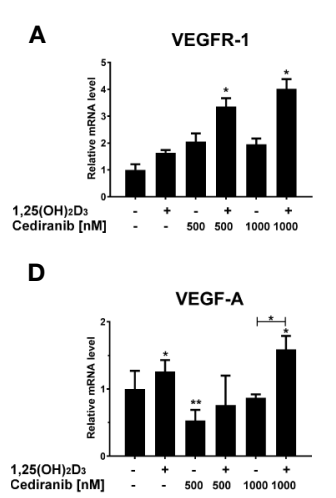

G

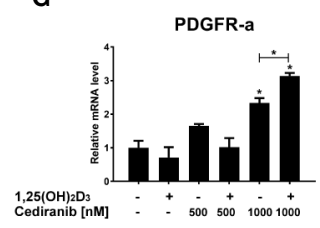

B

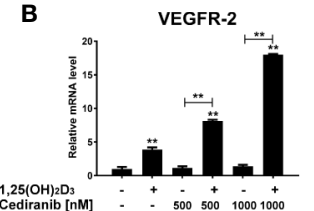

E

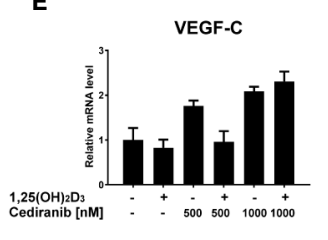

H

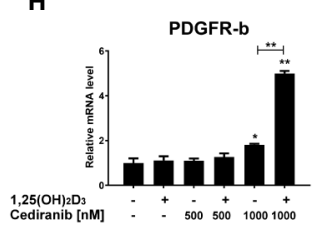

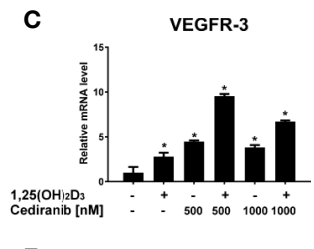

F

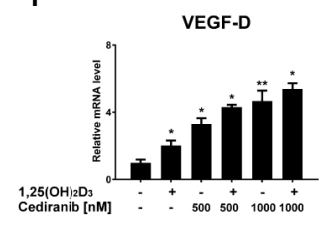

FIGURE 8 | The effect of 24-h preincubation with 1,25(OH) $)_{3}$ at 100 nM concentration on VEGFR1 (A), VEGFR2 (B), VEGFR3 (C), VEGFA (D), VEGFC (E), VEGFD (F), PDGFRa (G), and PDGFRb (H) gene expression in A375 melanoma cells treated subsequently for 24 h with cediranib at 500 or $1,000 \mathrm{nM}$ concentration. mRNA levels were measured by qPCR. The results are representative of three experiments carried out in duplicate. ${ }^{*} p<0.05$ and ${ }^{* *} p<0.01$ vs. untreated control or between the two groups indicated by the bracket.

effort in search for the neoadjuvant and adjuvant settings may therefore help to improve long-term outcomes for melanomasuffering patients. In that field, vitamin $\mathrm{D}$ seems to be a promising and reasonable remedy, acting as both a chemopreventive and therapeutic agent (47). Firstly, it is well documented that vitamin $\mathrm{D}$ protects against DNA damage (54, 55) and therefore against UV-induced carcinogenesis (56-58), since UV is considered as the major environmental risk factor for melanoma development (47). Secondly, vitamin D deficiency is a well-established cancer risk factor (59), while vitamin D supplementation was shown to reduce the incidence of advanced and fatal cancer (18). What is more, vitamin D deficiency is associated with higher Breslow thickness and mortality in melanoma patients (60). Furthermore, an increase in 25-hydroxyvitamin $\mathrm{D}_{3}$ level in vitamin $\mathrm{D}$-deficient melanoma patients already undergoing treatment improved their outcomes in comparison to individuals who remained vitamin D deficient (61). Finally, an inverse correlation between vitamin D receptor, VDR, and $1 \alpha$-hydroxylase (CYP27B1), the enzyme responsible for the synthesis of the biologically active form of vitamin D, was documented with melanoma progression and disease outcome $(25,26)$.
A

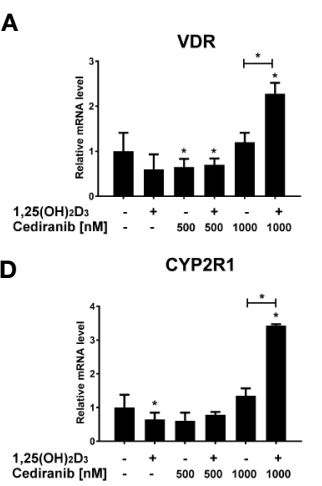

B

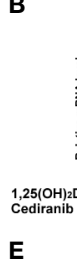

E
CYP27B1<smiles>[TeH4]</smiles>

C
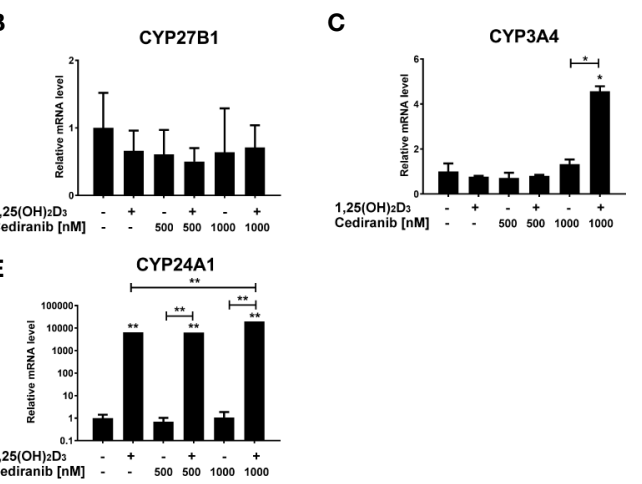

FIGURE 9 | The effect of 24-h preincubation with 1,25(OH) $\mathrm{D}_{3}$ at $100 \mathrm{nM}$ concentration on VDR (A), CYP27B1 (B), CYP3A4 (C), CYP2R1 (D), and CYP24A1 (E) gene expression in A375 melanoma cells treated subsequently for 24 h with cediranib at 500 or 1,000 nM concentration. mRNA levels were measured by qPCR. The results are representative of three experiments carried out in duplicate. ${ }^{*} p<0.05$ and ${ }^{\star *} p<0.01$ vs. untreated control or between the two groups indicated by the bracket. 
Our previous study revealed that two vitamin D analogs, calcitriol and low calcemic calcipotriol, exhibited modulatory effects on the A375 melanoma cells treated with dacarbazine, decreasing the half maximal inhibitory concentration (IC50, calcitriol only) for the drug, stimulating G1/G0 arrest, and causing a marked decrease in the mitochondrial transmembrane potential under given experimental conditions (30). Since the process of angiogenesis is crucial for growth, progression, and metastasis of the majority of solid tumors, including melanomas $(62,63)$, in the current study, the effects of cediranib, an oral tyrosine kinase inhibitor (TKI) of VEGFR13, PDGFR, and c-KIT (64), used in combination either with $1,25(\mathrm{OH})_{2} \mathrm{D}_{3}$ or with low-calcemic analog calcipotriol, were tested in the same A375 human malignant melanoma cell line, carrying the $\mathrm{BRAF}^{\mathrm{V} 600 \mathrm{E}}$ mutation, very common in melanoma patients (65), which was shown to be pro-angiogenic in several human tumors (66). Selected experiments were also carried out in MNT-1, RPMI-7951, and SK-MEL-28 melanoma cell lines. Cediranib as a single agent is associated predominantly with hypertension, diarrhea, dysphonia, and proteinuria, as shown in a phase I study (67). The most frequent non-hematologic adverse events observed in patients with metastatic or recurrent malignant melanoma treated with cediranib in a phase II study were hypertension (78\%), fatigue (69\%), diarrhea (69\%), and anorexia and nausea (each 57\%) (68). It should be emphasized that melanomas express high levels of VEGF, VEGFR1, VEGFR2, and VEGFR3, which is further associated with poor prognosis $(69,70)$. Quite unexpectedly, it was shown that adjuvant treatment with bevacizumab, an anti-VEGF monoclonal antibody, after resection of high-risk melanoma significantly improves disease-free interval, rather than overall survival (66). In fact, bevacizumab as a monotherapy does not offer any significant survival benefit over traditional therapies $(71,72)$. Therefore, antiangiogenic therapies in melanoma are rather supportive to other forms of treatment. However, various configurations of combination therapies with antiangiogenic bevacizumab against melanoma are currently being investigated in clinical trials (73). Very interestingly, as documented recently by Atzori (74), VEGFR1 inhibition might potentiate the effects of vemurafenib-based therapies for melanoma treatment and, what is more, counteract resistance development to this BRAF inhibitor, since the latter was associated with higher expression of VEGF receptors. Although cediranib alone was not sufficiently effective as a first-line therapy in untreated patients with metastatic or recurrent malignant melanoma, as shown in a phase II study (68), of the 17 patients evaluable for response, 2 patients had stable disease $>/=6$ months, and the disease was stable in 8 patients and progressive in 9 patients, with no objective responses seen. Still, the authors concluded that the potential of cediranib may be enhanced in combination with other agents (68). Furthermore, it was shown recently on patient-derived organoid models of endometrial cancer that cediranib but not bevacizumab synergizes with chemotherapy, decreasing cell viability when combined with paclitaxel as compared to treatment with paclitaxel alone (75). Currently, there is an ongoing phase I clinical trial, NCT01364051, for patients with clinically unresectable solid tumors, including stage IV cutaneous melanoma and malignant melanoma, and for whom there is no standard therapy, in which patients are receiving cediranib with selumetinib, an oral MEK 1/2 inhibitor. In our experiments, vitamin $\mathrm{D}$ derivatives were used at $100 \mathrm{nM}$ concentration, corresponding to the optimal serum $25(\mathrm{OH}) \mathrm{D}_{3}$ level $(75-125$ $\mathrm{nM}$ ) (76), which is used in clinic as a biomarker of vitamin D status. We have shown that supplementation with vitamin D improves the effectiveness of anti-angiogenic compound, cediranib, against A375 and SK-MEL-28 human melanoma cells, as we observed a marked decrease in melanoma cell proliferation (in both lines), G2/M cell cycle arrest, and a significant decrease in melanoma cell mobility (tested only in A375 melanoma cells). A similar observation was recently described in Hec50 cells, an endometrial adenocarcinoma, in which the combination of paclitaxel and cediranib produced a profound increase in the accumulation of cells in mitosis as assessed by the percentage of cells in G2/M by flow cytometry compared to paclitaxel alone (75). On the other hand, we did not observe any influence of vitamin D on proliferation of MNT-1 and RPMI-7951 melanoma cells treated with cediranib. The study of Atzori (74) suggested that VEGFR1 upregulation might contribute to melanoma progression and spreading. Overexpressed VEGFR2 in gastric cancer cells increased cellular proliferation and invasion in vitro as well as tumor formation in xenograft models (77). The pro-metastatic role of VEGFR2 was also postulated in osteosarcoma (78). Surprisingly, we observed the upregulation of VEGFR2 in experimental conditions used concurrently with a very desirable decrease in melanoma cell proliferation and mobility. Interestingly, it seems that vitamin $\mathrm{D}$ derivatives enhance cediranib efficacy by modulation of VEGFR2 expression in melanoma cells, as we observed a significant increase in VEGFR2 level at both protein and mRNA levels, along with the extracellular VEGFR2 expression, in vitamin D-pretreated A375 melanoma cells incubated further with cediranib. Thus, the extent to which vitamin $\mathrm{D}$ exacerbates cytotoxicity of cediranib against melanoma cells seems to depend firstly on the presence of VEGFR2 in these cells and secondly on its level. The most profound increase in cediranib cytotoxicity by supplementation with vitamin D was observed in A375 melanoma cells, in which we noticed the upregulation of VEGFR2, at both the protein and mRNA level, as well as its extracellular expression, in experimental conditions used, concurrently with a very desirable decrease in melanoma cell proliferation and mobility. The VEGFR2 protein level was several times higher in vitamin D-pretreated cells compared to monotreatment with cediranib. Similarly, in SK-MEL-28 cells, simultaneous treatment with cediranib and $1,25(\mathrm{OH})_{2} \mathrm{D}_{3}$ or calcipotriol, at $100 \mathrm{nM}$ concentration, resulted in a further decrease in the proliferation of these melanoma cells, which was accompanied by an increase in the protein level of VEGFR2 compared to control cells in experimental conditions used, although there was no difference in the VEGFR2 protein level compared to monotreatment with cediranib. On the other hand, in MNT-1 
and RPMI-7951 melanoma cells, in which we did not observe any enhancement of cediranib cytotoxicity by supplementation with vitamin $\mathrm{D}$, we did not detect any VEGFR2 protein in the experimental conditions used. It should be noted that VEGFR2 is considered a predominant receptor triggering VEGF signaling in cells $(73,79)$. Out of the three primary VEGF receptors, VEGFR2 is considered the dominant effector and the most relevant in the metastatic melanoma microenvironment, although the study of Molhoek and coworkers showed that a relatively low percentage of melanoma cells express VEGFR2 (80). However, yet another study underlines that it is VEGFR2 that might be a new prognostic marker in malignant melanoma (81).

Possibly, the astonishing upregulation of VEGFR2 observed in A375 and SK-MEL-28 melanoma cells in our experimental conditions may be considered as an adaptive strategy activated by vitamin $\mathrm{D}$, in which increased availability of VEGFR2 on the melanoma cell surface potentiates the response to its inhibitor, cediranib, or elevated expression of the receptor is a response to inhibition of the downstream signaling from the receptor.

We also observed an increase in VDR mRNA level as well as CYP3A4 and CYP2R1 in A375 cells, the enzymes responsible for 25-hydroxylation of vitamin $\mathrm{D}$ en route to its final activation, in melanoma cells treated with cediranib at $1,000 \mathrm{nM}$ concentration, which were $1,25(\mathrm{OH})_{2} \mathrm{D}_{3}$ pretreated, underlining an intensified vitamin $\mathrm{D}$ activation in these conditions $(p<0.05$, Figure 9). Thus, it is possible that cediranib actually improves the sensitivity of cells to vitamin $\mathrm{D}$.

In conclusion, although recent innovative immunotherapies and targeted therapies have vastly ameliorated the management of metastatic melanoma, in light of impending resistance development, more effective strategies for treatment of melanoma patients are still urgently needed. We demonstrated that vitamin $\mathrm{D}$ derivatives hold promise as novel adjuvant candidates to conquer melanoma, which may be considered for clinical applications, especially in vitamin D-deficient melanoma patients, as they are widely available, non-toxic, and relatively inexpensive. However, further extensive and complex studies are needed to assess their potential expected benefits for melanoma patients.

\section{REFERENCES}

1. Thomas D, Bello DM. Adjuvant Immunotherapy for Melanoma. J Surg Oncol (2021) 123(3):789-97. doi: 10.1002/jso.26329

2. Eddy K, Shah R, Chen S. Decoding Melanoma Development and Progression: Identification of Therapeutic Vulnerabilities. Front Oncol (2020) 10:626129. doi: $10.3389 /$ fonc. 2020.626129

3. Patton EE, Mueller KL, Adams DJ, Anandasabapathy N, Aplin AE, Bertolotto C, et al. Melanoma Models for the Next Generation of Therapies. Cancer Cell (2021) 39(5):610-31. doi: 10.1016/j.ccell.2021.01.011

4. Ascierto PA, Puzanov I, Agarwala SS, Blank C, Carvajal RD, Demaria S, et al. Perspectives in Melanoma: Meeting Report From the "Melanoma Bridge" (December 5th-7th, 2019, Naples, Italy). J Transl Med (2020) 18(1):346. doi: 10.1186/s12967-020-02482-x

5. Berk-Krauss J, Stein JA, Weber J, Polsky D, Geller AC. New Systematic Therapies and Trends in Cutaneous Melanoma Deaths Among US Whites, 1986-2016. Am J Public Health (2020) 110(5):731-3. doi: 10.2105/AJPH.2020.305567

6. Trotta AP, Gelles JD, Serasinghe MN, Loi P, Arbiser JL, Chipuk JE. Disruption of Mitochondrial Electron Transport Chain Function

\section{DATA AVAILABILITY STATEMENT}

The datasets used and/or analyzed during the current study are available from the corresponding author on reasonable request.

\section{AUTHOR CONTRIBUTIONS}

$\mathrm{AP}$ and MAŻ conceived, designed, and supervised the study. AP, FBP, JIN, and JMW performed the experiments. AP and MAŻ analyzed the data. AP and MAŻ wrote the manuscript. All authors contributed to the article and approved the submitted version.

\section{FUNDING}

This study was supported by grant no. MN 01-0250/08/280 from the Medical University of Gdansk (Gdansk, Poland) to AP. The authors would like also to thank São Paulo Research Foundation (FAPESP) for the grant support: 2017/17600-1.

\section{SUPPLEMENTARY MATERIAL}

The Supplementary Material for this article can be found online at: https://www.frontiersin.org/articles/10.3389/fonc.2021.763895/ full\#supplementary-material

Supplementary Figure 1 | The effect of 24 hours preincubation with vitamin D analogs at $100 \mathrm{nM}$ concentration on the distribution of human malignant melanoma A375 cells treated for 72 hours with cediranib throughout phases of the cell cycle (M1: SubG1 - apoptotic/necrotic cells, M2: G1 - growth, M3: S-DNA synthesis, M4: G2/M-preparation for mitosis/mitosis). Cells were harvested, stained with propidium iodide and analyzed by Flow Cytometry. Presented panels show representative data plots for relevant treatments.

Supplementary Figure 2 | The effect of 24 hours preincubation with vitamin D analogs at $100 \mathrm{nM}$ concentration on the extracellular expression of the VEGFR2 in A375 melanoma cells treated subsequently for 24 hours with cediranib at 500 or $1000 \mathrm{nM}$ concentration. Cells were stained with appropriate antibody (see Materials and methods section) and analyzed cytometrically. Presented panels show representative data plots for relevant treatments.

Potentiates the Pro-Apoptotic Effects of MAPK Inhibition. J Biol Chem (2017) 292(28):11727-39. doi: 10.1074/jbc.M117.786442

7. Trojaniello C, Vitale MG, Scarpato L, Esposito A, Ascierto PA. Melanoma Immunotherapy: Strategies to Overcome Pharmacological Resistance. Expert Rev Anticancer Ther (2020) 20(4):289-304. doi: 10.1080/14737140.2020. 1745634

8. Imbert C, Montfort A, Fraisse M, Marcheteau E, Gilhodes J, Martin E, et al. Resistance of Melanoma to Immune Checkpoint Inhibitors Is Overcome by Targeting the Sphingosine Kinase-1. Nat Commun (2020) 11(1):437. doi: 10.1038/s41467-019-14218-7

9. Siegel RL, Miller KD, Fuchs HE, Jemal A. Cancer Statistics, 2021. CA Cancer J Clin (2021) 71(1):7-33. doi: 10.3322/caac.21654

10. Chen J, Tang Z, Slominski AT, Li W, Żmijewski MA, Liu Y. Vitamin D and its Analogs as Anticancer and Anti-Inflammatory Agents. Eur J Med Chem (2020) 207:112738. doi: 10.1016/j.ejmech.2020.112738

11. Slominski AT, Brozyna AA, Zmijewski MA, Jozwicki W, Jetten AM, Mason RS, et al. Vitamin D Signaling and Melanoma: Role of Vitamin D and its Receptors in Melanoma Progression and Management. Lab Invest (2017) 97 (6):706-24. doi: 10.1038/labinvest.2017.3 
12. Jeon SM, Shin EA. Exploring Vitamin D Metabolism and Function in Cancer. Exp Mol Med (2018) 50(4):1-14. doi: 10.1038/s12276-018-0038-9

13. Chang SW, Lee HC. Vitamin D and Health - The Missing Vitamin in Humans. Pediatr Neonatol (2019) 60(3):237-44. doi: 10.1016/j.pedneo.2019.04.007

14. Wierzbicka J, Piotrowska A, Zmijewski MA. The Renaissance of Vitamin D. Acta Biochim Pol (2014) 61:679-86. doi: 10.18388/abp.2014_1830

15. Piotrowska A, Wierzbicka J, Kwiatkowska K, Chodyński M, Kutner A, Żmijewski MA. Antiproliferative Activity of Side-Chain Truncated Vitamin D Analogs (PRI-1203 and PRI-1204) Against Human Malignant Melanoma Cell Lines. Eur J Pharmacol (2020) 881:173170. doi: 10.1016/j.ejphar. 2020.173170

16. Manson JE, Cook NR, Lee IM, Christen W, Bassuk SS, Mora S, et al. Vitamin D Supplements and Prevention of Cancer and Cardiovascular Disease. N Engl J Med (2019) 380(1):33-44. doi: 10.1056/NEJMoa1809944

17. Grant WB, Boucher BJ. Why Secondary Analyses in Vitamin D Clinical Trials Are Important and How to Improve Vitamin D Clinical Trial Outcome Analyses-A Comment on "Extra-Skeletal Effects of Vitamin D, Nutrients 2019, 11, 1460". Nutrients 11(9):2182. doi: 10.3390/nu11092182

18. Chandler PD, Chen WY, Ajala ON, Hazra A, Cook N, Bubes V, et al. Effect of Vitamin D3 Supplements on Development of Advanced Cancer: A Secondary Analysis of the VITAL Randomized Clinical Trial. JAMA Netw Open (2020) 3 (11):e2025850. doi: 10.1001/jamanetworkopen.2020.25850

19. Lappe JM, Travers-Gustafson D, Davies KM, Recker RR, Heaney RP. Vitamin $\mathrm{D}$ and Calcium Supplementation Reduces Cancer Risk: Results of a Randomized Trial. Am J Clin Nutr (2007) 85(6):1586-91. doi: 10.1093/ajcn/ 85.6.1586

20. Holick MF. Cancer, Sunlight and Vitamin D. J Clin Transl Endocrinol (2014) 1 (4):179-86. doi: 10.1016/j.jcte.2014.10.001

21. Johansson H, Spadola G, Tosti G, Mandalà M, Minisini AM, Queirolo P, et al. Vitamin D Supplementation and Disease-Free Survival in Stage II Melanoma: A Randomized Placebo Controlled Trial. Nutrients (2021) 13(6):1931. doi: $10.3390 /$ nu13061931

22. Gupta M, Maamoun W, Maher M, Jaffe W. Ensuring Universal Assessment and Management of Vitamin D Status in Melanoma Patients at Secondary Care Level: A Service Improvement Project. Br J Hosp Med (Lond) (2020) 81 (10):1-5. doi: 10.12968/hmed.2020.0128

23. De Smedt J, Van Kelst S, Boecxstaens V, Stas M, Bogaerts K, Vanderschueren D, et al. Vitamin D Supplementation in Cutaneous Malignant Melanoma Outcome (ViDMe): A Randomized Controlled Trial. BMC Cancer (2017) 17 (1):562. doi: 10.1186/s12885-017-3538-4

24. Brozyna AA, Jozwicki W, Janjetovic Z, Slominski AT. Expression of Vitamin D Receptor Decreases During Progression of Pigmented Skin Lesions. Hum Pathol (2011) 42(5):618-31. doi: 10.1016/j.humpath.2010.09.014

25. Brozyna AA, Jozwicki W, Janjetovic Z, Slominski AT. Expression of the Vitamin D-Activating Enzyme 1alpha-Hydroxylase (CYP27B1) Decreases During Melanoma Progression. Hum Pathol (2013) 44(3):374-87. doi: 10.1016/j.humpath.2012.03.031

26. Brozyna AA, Jozwicki W, Slominski AT. Decreased VDR Expression in Cutaneous Melanomas as Marker of Tumor Progression: New Data and Analyses. Anticancer Res (2014) 34(6):2735-43.

27. Muralidhar S, Filia A, Nsengimana J, Poźniak J, O'Shea SJ, Diaz JM, et al. Vitamin D-VDR Signaling Inhibits Wnt/B-Catenin-Mediated Melanoma Progression and Promotes Antitumor Immunity. Cancer Res (2019) 79 (23):5986-98. doi: 10.1158/0008-5472.CAN-18-3927

28. Ma Y, Yu WD, Trump DL, Johnson CS. 1,25D3 Enhances Antitumor Activity of Gemcitabine and Cisplatin in Human Bladder Cancer Models. Cancer (2010) 116(13):3294-303. doi: 10.1002/cncr.25059

29. Huang Z, Zhang Y, Li H, Zhou Y, Zhang Q, Chen R, et al. Vitamin D Promotes the Cisplatin Sensitivity of Oral Squamous Cell Carcinoma by Inhibiting LCN2-Modulated NF-kb Pathway Activation Through RPS3. Cell Death Dis (2019) 10(12):936. doi: 10.1038/s41419-019-2177-x

30. Piotrowska A, Wierzbicka J, Rybarczyk A, Tuckey RC, Slominski AT, Zmijewski MA. Vitamin D and its Low Calcemic Analogs Modulate the Anticancer Properties of Cisplatin and Dacarbazine in the Human Melanoma A375 Cell Line. Int J Oncol (2019) 54(4):1481-95. doi: 10.3892/ijo.2019.4725

31. Wietrzyk J, Nevozhay D, Filip B, Milczarek M, Kutner A. The Antitumor Effect of Lowered Doses of Cytostatics Combined With New Analogs of Vitamin D in Mice. Anticancer Res (2007) 27(5a):3387-98.
32. Podgorska E, Drzal A, Matuszak Z, Swakon J, Slominski A, Elas M, et al. Calcitriol and Calcidiol Can Sensitize Melanoma Cells to Low(-)LET Proton Beam Irradiation. Int J Mol Sci (2018) 19(8):2236. doi: 10.3390/ijms19082236

33. Stucci LS, D'Oronzo S, Tucci M, Macerollo A, Ribero S, Spagnolo F, et al. Vitamin D in Melanoma: Controversies and Potential Role in Combination With Immune Check-Point Inhibitors. Cancer Treat Rev (2018) 69:21-8. doi: 10.1016/j.ctrv.2018.05.016

34. Araki T, Holick MF, Alfonso BD, Charlap E, Romero CM, Rizk D, et al. Vitamin D Intoxication With Severe Hypercalcemia Due to Manufacturing and Labeling Errors of Two Dietary Supplements Made in the United States. J Clin Endocrinol Metab (2011) 96(12):3603-8. doi: 10.1210/jc.2011-1443

35. Holick MF, Binkley NC, Bischoff-Ferrari HA, Gordon CM, Hanley DA, Heaney RP, et al. Evaluation, Treatment, and Prevention of Vitamin D Deficiency: An Endocrine Society Clinical Practice Guideline. J Clin Endocrinol Metab (2011) 96(7):1911-30. doi: 10.1210/jc.2011-0385

36. McCullough PJ, Lehrer DS, Amend J. Daily Oral Dosing of Vitamin D3 Using 5000 TO 50,000 International Units a Day in Long-Term Hospitalized Patients: Insights From a Seven Year Experience. J Steroid Biochem Mol Biol (2019) 189:228-39. doi: 10.1016/j.jsbmb.2018.12.010

37. Koul PA, Ahmad SH, Ahmad F, Jan RA, Shah SU, Khan UH. Vitamin D Toxicity in Adults: A Case Series From an Area With Endemic Hypovitaminosis D. Oman Med J (2011) 26(3):201-4. doi: 10.5001/ omj.2011.49

38. Slominski AT, Janjetovic Z, Kim TK, Wright AC, Grese LN, Riney SJ, et al. Novel Vitamin D Hydroxyderivatives Inhibit Melanoma Growth and Show Differential Effects on Normal Melanocytes. Anticancer Res (2012) 32 (9):3733-42.

39. Slominski AT, Brożyna AA, Skobowiat C, Zmijewski MA, Kim TK, Janjetovic Z, et al. On the Role of Classical and Novel Forms of Vitamin D in Melanoma Progression and Management. J Steroid Biochem Mol Biol (2018) 177:159-70. doi: $10.1016 /$ j.jsbmb.2017.06.013

40. Slominski AT, Kim TK, Shehabi HZ, Semak I, Tang EK, Nguyen MN, et al. In Vivo Evidence for a Novel Pathway of Vitamin D(3) Metabolism Initiated by P450scc and Modified by CYP27B1. FASEB J (2012) 26(9):3901-15. doi: 10.1096/fj.12-208975

41. Slominski AT, Kim TK, Shehabi HZ, Tang EK, Benson HA, Semak I, et al. In Vivo Production of Novel Vitamin D2 Hydroxy-Derivatives by Human Placentas, Epidermal Keratinocytes, Caco-2 Colon Cells and the Adrenal Gland. Mol Cell Endocrinol (2014) 383(1-2):181-92. doi: 10.1016/ j.mce.2013.12.012

42. Slominski AT, Li W, Kim TK, Semak I, Wang J, Zjawiony JK, et al. Novel Activities of CYP11A1 and Their Potential Physiological Significance. J Steroid Biochem Mol Biol (2015) 151:25-37. doi: 10.1016/j.jsbmb.2014.11.010

43. Slominski AT, Kim TK, Li W, Postlethwaite A, Tieu EW, Tang EK, et al. Detection of Novel CYP11A1-Derived Secosteroids in the Human Epidermis and Serum and Pig Adrenal Gland. Sci Rep (2015) 5:14875. doi: 10.1038/ srep 14875

44. Piotrowska A, Wierzbicka J, Nadkarni S, Brown G, Kutner A, Zmijewski MA. Antiproliferative Activity of Double Point Modified Analogs of 1,25Dihydroxyvitamin D(2) Against Human Malignant Melanoma Cell Lines. Int J Mol Sci (2016) 17(1):76. doi: 10.3390/ijms17010076

45. Zmijewski MA, Li W, Chen J, Kim TK, Zjawiony JK, Sweatman TW, et al. Synthesis and Photochemical Transformation of 3beta,21Dihydroxypregna-5,7-Dien-20-One to Novel Secosteroids That Show Anti-Melanoma Activity. Steroids (2011) 76(1-2):193-203. doi: 10.1016/ j.steroids.2010.10.009

46. Avram S, Coricovac DE, Pavel IZ, Pinzaru I, Ghiulai R, Baderca F, et al. Standardization of A375 Human Melanoma Models on Chicken Embryo Chorioallantoic Membrane and Balb/c Nude Mice. Oncol Rep (2017) 38 (1):89-99. doi: 10.3892/or.2017.5658

47. Brozyna AA, Hoffman RM, Slominski AT. Relevance of Vitamin D in Melanoma Development, Progression and Therapy. Anticancer Res (2020) 40(1):473-89. doi: 10.21873/anticanres.13976

48. Sample A, He YY. Mechanisms and Prevention of UV-Induced Melanoma. Photodermatol Photoimmunol Photomed (2018) 34(1):13-24. doi: 10.1111/ phpp.12329

49. Piotrowska A, Wierzbicka J, Slebioda T, Wozniak M, Tuckey RC, Slominski AT, et al. Vitamin D Derivatives Enhance Cytotoxic Effects of $\mathrm{H} 2 \mathrm{O} 2$ or 
Cisplatin on Human Keratinocytes. Steroids (2016) 110:49-61. doi: 10.1016/ j.steroids.2016.04.002

50. Wang X, Lan H, Li J, Su Y, Xu L. Mucl Promotes Migration and Lung Metastasis of Melanoma Cells. Am J Cancer Res (2015) 5(9):2590-604.

51. Matulonis UA, Berlin S, Ivy P, Tyburski K, Krasner C, Zarwan C, et al. Cediranib, an Oral Inhibitor of Vascular Endothelial Growth Factor Receptor Kinases, is an Active Drug in Recurrent Epithelial Ovarian, Fallopian Tube, and Peritoneal Cancer. J Clin Oncol (2009) 27(33):5601-6. doi: 10.1200/ JCO.2009.23.2777

52. Kaur G, Lakkaraju A. Early Endosome Morphology in Health and Disease. Adv Exp Med Biol (2018) 1074:335-43. doi: 10.1007/978-3-319-75402-4_41

53. Reichrath J, Rech M, Moeini M, Meese E, Tilgen W, Seifert M. In Vitro Comparison of the Vitamin D Endocrine System in 1,25(OH)2D3-Responsive and -Resistant Melanoma Cells. Cancer Biol Ther (2007) 6(1):48-55. doi: 10.4161/cbt.6.1.3493

54. Slominski AT, Janjetovic Z, Kim TK, Wasilewski P, Rosas S, Hanna S, et al. Novel non-Calcemic Secosteroids That are Produced by Human Epidermal Keratinocytes Protect Against Solar Radiation. J Steroid Biochem Mol Biol (2015) 148:52-63. doi: 10.1016/j.jsbmb.2015.01.014

55. Gordon-Thomson C, Gupta R, Tongkao-on W, Ryan A, Halliday GM, Mason RS. 1alpha,25 Dihydroxyvitamin D3 Enhances Cellular Defences Against UVInduced Oxidative and Other Forms of DNA Damage in Skin. Photochem Photobiol Sci (2012) 11(12):1837-47. doi: 10.1039/c2pp25202c

56. Jiang YJ, Teichert AE, Fong F, Oda Y, Bikle DD. 1alpha,25(OH)2Dihydroxyvitamin D3/VDR Protects the Skin From UVB-Induced Tumor Formation by Interacting With the Beta-Catenin Pathway. J Steroid Biochem Mol Biol (2013) 136:229-32. doi: 10.1016/j.jsbmb.2012.09.024

57. Bikle DD, Jiang Y, Nguyen T, Oda Y, Tu CL. Disruption of Vitamin D and Calcium Signaling in Keratinocytes Predisposes to Skin Cancer. Front Physiol (2016) 7:296. doi: 10.3389/fphys.2016.00296

58. Holick MF. Sunlight, Ultraviolet Radiation, Vitamin D and Skin Cancer: How Much Sunlight do We Need? Adv Exp Med Biol (2014) 810:1-16. doi: 10.1007/ 978-1-4939-0437-2_1

59. Yin L, Ordonez-Mena JM, Chen T, Schottker B, Arndt V, Brenner H. Circulating 25-Hydroxyvitamin D Serum Concentration and Total Cancer Incidence and Mortality: A Systematic Review and Meta-Analysis. Prev Med (2013) 57(6):753-64. doi: 10.1016/j.ypmed.2013.08.026

60. Tsai TY, Kuo CY, Huang YC. The Association Between Serum Vitamin D Level and Risk and Prognosis of Melanoma: A Systematic Review and Meta-Analysis. $J$ Eur Acad Dermatol Venereol (2020) 34(8):1722-9. doi: 10.1111/jdv.16189

61. Timerman D, McEnery-Stonelake M, Joyce CJ, Nambudiri VE, Hodi FS, Claus EB, et al. Vitamin D Deficiency is Associated With a Worse Prognosis in Metastatic Melanoma. Oncotarget (2017) 8(4):6873-82. doi: 10.18632/oncotarget.14316

62. Delgado-Hernández R, Hernández-Balmaseda I, Rodeiro-Guerra I, Cesar Rodriguez Gonzalez J, De Wever O, Logie E, et al. Anti-Angiogenic Effects of Mangiferin and Mechanism of Action in Metastatic Melanoma. Melanoma Res (2020) 30(1):39-51. doi: 10.1097/CMR.0000000000000647

63. Simonsen TG, Gaustad JV, Rofstad EK. Bevacizumab Treatment of Meningeal Melanoma Metastases. J Transl Med (2020) 18(1):13. doi: 10.1186/s12967020-02212-3

64. Tsao AS, Moon J, Wistuba II, Vogelzang NJ, Kalemkerian GP, Redman MW, et al. Phase I Trial of Cediranib in Combination With Cisplatin and Pemetrexed in Chemonaive Patients With Unresectable Malignant Pleural Mesothelioma (SWOG S0905). J Thorac Oncol (2017) 12(8):1299-308. doi: 10.1016/j.jtho.2017.05.021

65. Chacon AC, Melucci AD, Qin SS, Prieto PA. Thinking Small: Small Molecules as Potential Synergistic Adjuncts to Checkpoint Inhibition in Melanoma. Int $J$ Mol Sci (2021) 22(6):3228. doi: 10.3390/ijms22063228

66. Corrie PG, Marshall A, Nathan PD, Lorigan P, Gore M, Tahir S, et al. Adjuvant Bevacizumab for Melanoma Patients at High Risk of Recurrence: Survival Analysis of the AVAST-M Trial. Ann Oncol (2018) 29(8):1843-52. doi: 10.1093/annonc/mdy229

67. Drevs J, Siegert P, Medinger M, Mross K, Strecker R, Zirrgiebel U, et al. Phase I Clinical Study of AZD2171, an Oral Vascular Endothelial Growth Factor Signaling Inhibitor, in Patients With Advanced Solid Tumors. J Clin Oncol (2007) 25(21):3045-54. doi: 10.1200/JCO.2006.07.2066
68. McWhirter E, Quirt I, Gajewski T, Pond G, Wang L, Hui J, et al. A Phase II Study of Cediranib, an Oral VEGF Inhibitor, in Previously Untreated Patients With Metastatic or Recurrent Malignant Melanoma. Invest New Drugs (2016) 34(2):231-5. doi: 10.1007/s10637-016-0324-0

69. Domingues B, Lopes JM, Soares P, Populo H. Melanoma Treatment in Review. Immunotargets Ther (2018) 7:35-49. doi: 10.2147/ITT.S134842

70. Mehnert JM, McCarthy MM, Jilaveanu L, Flaherty KT, Aziz S, Camp RL, et al. Quantitative Expression of VEGF, VEGF-R1, VEGF-R2, and VEGF-R3 in Melanoma Tissue Microarrays. Hum Pathol (2010) 41(3):375-84. doi: 10.1016/j.humpath.2009.08.016

71. Jour G, Ivan D, Aung PP. Angiogenesis in Melanoma: An Update With a Focus on Current Targeted Therapies. J Clin Pathol (2016) 69(6):472-83. doi: 10.1136/jclinpath-2015-203482

72. D'Aguanno S, Mallone F, Marenco M, Del Bufalo D, Moramarco A. HypoxiaDependent Drivers of Melanoma Progression. J Exp Clin Cancer Res (2021) 40 (1):159. doi: 10.1186/s13046-021-01926-6

73. Bogusławska-Duch J, Ducher M, Małecki M. Resistance of Melanoma Cells to Anticancer Treatment: A Role of Vascular Endothelial Growth Factor. Postepy Dermatol Alergol (2020) 37(1):11-8. doi: 10.5114/ada.2020.93378

74. Atzori MG, Ceci C, Ruffini F, Trapani M, Barbaccia ML, Tentori L, et al. Role of VEGFR-1 in Melanoma Acquired Resistance to the BRAF Inhibitor Vemurafenib. J Cell Mol Med (2020) 24(1):465-75. doi: 10.1111/jcmm.14755

75. Bi J, Dixit G, Zhang Y, Devor EJ, Losh HA, Newtson AM, et al. Advantages of Tyrosine Kinase Anti-Angiogenic Cediranib Over Bevacizumab: Cell Cycle Abrogation and Synergy With Chemotherapy. Pharm (Basel) (2021) 14 (7):682. doi: 10.3390/ph14070682

76. Pludowski P, Holick MF, Grant WB, Konstantynowicz J, Mascarenhas MR, Haq A, et al. Vitamin D Supplementation Guidelines. J Steroid Biochem Mol Biol (2018) 175:125-35. doi: 10.1016/j.jsbmb.2017.01.021

77. Lian L, Li XL, Xu MD, Li XM, Wu MY, Zhang Y, et al. VEGFR2 Promotes Tumorigenesis and Metastasis in a Pro-Angiogenic-Independent Way in Gastric Cancer. BMC Cancer (2019) 19(1):183. doi: 10.1186/s12885-019$5322-0$

78. Zheng B, Zhou C, Qu G, Ren C, Yan P, Guo W, et al. VEGFR2 Promotes Metastasis and PD-L2 Expression of Human Osteosarcoma Cells by Activating the STAT3 and RhoA-ROCK-LIMK2 Pathways. Front Oncol (2020) 10:543562. doi: 10.3389/fonc.2020.543562

79. Pisacane AM, Risio M. VEGF and VEGFR-2 Immunohistochemistry in Human Melanocytic Naevi and Cutaneous Melanomas. Melanoma Res (2005) 15(1):39-43. doi: 10.1097/00008390-200502000-00007

80. Molhoek KR, Erdag G, Rasamny JK, Murphy C, Deacon D, Patterson JW, et al. VEGFR-2 Expression in Human Melanoma: Revised Assessment. Int $J$ Cancer (2011) 129(12):2807-15. doi: 10.1002/ijc.25963

81. Seyed Jafari SM, Wiedmer C, Cazzaniga S, Frangež Ž, Shafighi M, Beltraminelli H, et al. Correlation of Vascular Endothelial Growth Factor Subtypes and Their Receptors With Melanoma Progression: A NextGeneration Tissue Microarray (ngTMA) Automated Analysis. PloS One (2018) 13(11):e0207019. doi: 10.1371/journal.pone.0207019

Conflict of Interest: The authors declare that the research was conducted in the absence of any commercial or financial relationships that could be construed as a potential conflict of interest.

Publisher's Note: All claims expressed in this article are solely those of the authors and do not necessarily represent those of their affiliated organizations, or those of the publisher, the editors and the reviewers. Any product that may be evaluated in this article, or claim that may be made by its manufacturer, is not guaranteed or endorsed by the publisher.

Copyright $\odot 2021$ Piotrowska, Beserra, Wierzbicka, Nowak and Żmijewski. This is an open-access article distributed under the terms of the Creative Commons Attribution License (CC BY). The use, distribution or reproduction in other forums is permitted, provided the original author(s) and the copyright owner(s) are credited and that the original publication in this journal is cited, in accordance with accepted academic practice. No use, distribution or reproduction is permitted which does not comply with these terms. 